\title{
Endogenous oscillations of electric potential difference in the cambial region of the pine stem. II. Possible involvement of the oscillations in xylogenesis
}

\author{
WOJCIECH KUREK*
}

\begin{abstract}
Department of Forest Botany, Warsaw Agricultural University, Rakowiecka 26/30, 02-528 Warsaw, Poland
\end{abstract}

(Received: April 3, 1991. Accepted: October 30, 1991)

\begin{abstract}
Direct and indirect interrelations between xylogenic processes and the endogenous electric potential difference (PD) oscillations generated in the cambial region of isolated tissue blocks from pine trunks were investigated. The frequency of transient PD changes varied during the season and displayed three minima which were concurrent with periods of initiation and termination of cambial activity and with the time of transition from early- to late-wood production. The oscillations were damped by TIBA - an inhibitor of polar auxin transport and stimulated by IAA, but only when the hormone was supplied to the apical end of the tissue block. This suggests that the polar transport of auxin may be involved in generation of the transient PD changes. Results of 2-channel recordings in one tissue block suggest that a part of the recorded oscillations (10-25\%) exhibit coordination in space and time: a wave-like pattern along the trunk axis is created by PD changes. The pattern might be a physical carrier of information coordinating processes of growth and differentiation in distant parts of the tree.
\end{abstract}

Key words: electric oscillations, xylogenesis, polar auxin transport, Scots pine

\section{INTRODUCTION}

Electrophysiological events in plants with no rapid motor response are considered by some authors as being connected with processes of growth and differentiation. Experimental studies (e.g. Sin yukhin and Stolarek $1961, \mathrm{~K}$ at ou and Okam ot o 1970 , Novakand Bentrup 1972, I chi -

* Present address: Department of Botany, Institute of Plant Biology, Warsaw Agricultural University, Rakowiecka 26/30, 02-528 Warsaw, Poland. 
no et al. 1973, Weisenseel et al. 1979, Medvedev and Markova 1990) carried out by different methods on diverse plant objects as well as more theoretical papers (Gradmann and Mummert 1980, Jaffe 1982) point to a close interrelation between electrophysiological events and different aspects of plant morphogenesis. This point of view is supported by numerous studies reporting the effect of important morphogenetic factors-phytohormones on the membrane potential $\left(E_{m}\right)$, e.g. Etherton (1970), J a mes et al. (1976), Cleland et al. (1977), B a llarin-Denti and Cocucci (1979). Similarly, many authors observed PD fluctuations at the tissue or organ level, induced by auxins (e.g. Scott 1957, New m a n 1963, Sinyukhin and Gorchakov 1966, Morath and Hertel 1978, H e j n ow icz et al. 1986).

In spite of quite numerous results indicating interrelations between electrophysiological events and morphogenetic processes the mechanism of functioning of the system is still obscure. This study tends to approach this problem with the use of a woody plant as the experimental object. Endogenous PD oscillations in the cambial region of Scots pine were described in a previous paper (K u r e k 1992). Considering the role of cambium in formation of secondary wood one can hypothesise that electrophysiological events may be involved in xylogenetic processes in a woody plant. To test this possibility the PD oscillations were further investigated with respect to their seasonal changes, sensitivity to auxin and potential ability to propagate along the trunk axis.

\section{MATERIAL AND METHODS}

Measurements were made on isolated tissue blocks (ca. $15 \mathrm{~cm}$ long) taken from 80 -year-old Scots pine trees, by means of extracellular electrodes connected to a direct current amplifier. Material, experimental preparation, measuring apparatus and data elaboration are described in detail in a previous paper (K u r e k 1992). Indole-3-acetic acid [IAA] in a concentration $5.7 \times 10^{-2} \mathrm{mM}$ and 2,3,5-triiodobenzoic acid [TIBA] in a $0.1 \mathrm{mM}$ or $0.4 \mathrm{mM}$ concentration were applied to the blocks by means of soaking and in some experiments the physiologically active substance was placed in an agar strip on the apical end of the tissue block and kept there throughout the measurement . Additionally, some experimental manipulations were performed on trees growing in the forest to differentiate the auxin level in the cambial region of the stem. This was done by ring-barking 80 -year-old pines at the height of $1.7 \mathrm{~m}$ in early October. Within the girdles $(10 \mathrm{~cm}$ wide) all tissues external to the differentiated xylem were removed. The bare strip was protected against drying by means of lanoline covered with a sheet of plastic. The tissue was collected above and under the girdle in July and August of the next year. Two parallel measurements were performed in the laboratory: on the block of tissue from above and from below the girdle. 


\section{RESULTS}

SEASONAL VARIATION OF PD OSCILLATIONS IN THE STEM CAMBIAL REGION

Measurements were performed on tissue blocks collected from 80-year-old pines from the end of February to December, 1984. Oscillations were counted in each 6-hour electrophytogram - a plot of PD in function of time and divided into classes of amplitudes similar to those described in the previous paper (K u r e k 1992). A separate season plot was drawn for each class of amplitudes. Diagrams are shown only for two classes: $<0.1,1) \mathrm{mV}$ and $\geqslant 0.1 \mathrm{mV}$ in Fig. 1 . The seasonal pattern of frequency of the oscillatons exhibited two minima: at the end of June and at the and of September (Fig. 1A and B). The minima are better visible after transformation of the data with the use of a moving average for three terms (Y u le and Kendall 1966) - Fig. 1C and D. Additional seasonal measurements in 1986 confirmed the early-summer minimum (in that year it was slightly shifted toward July) and revealed the third minimum in the second half of April which had been hardly observable in 1984 (Fig. 1E-H).
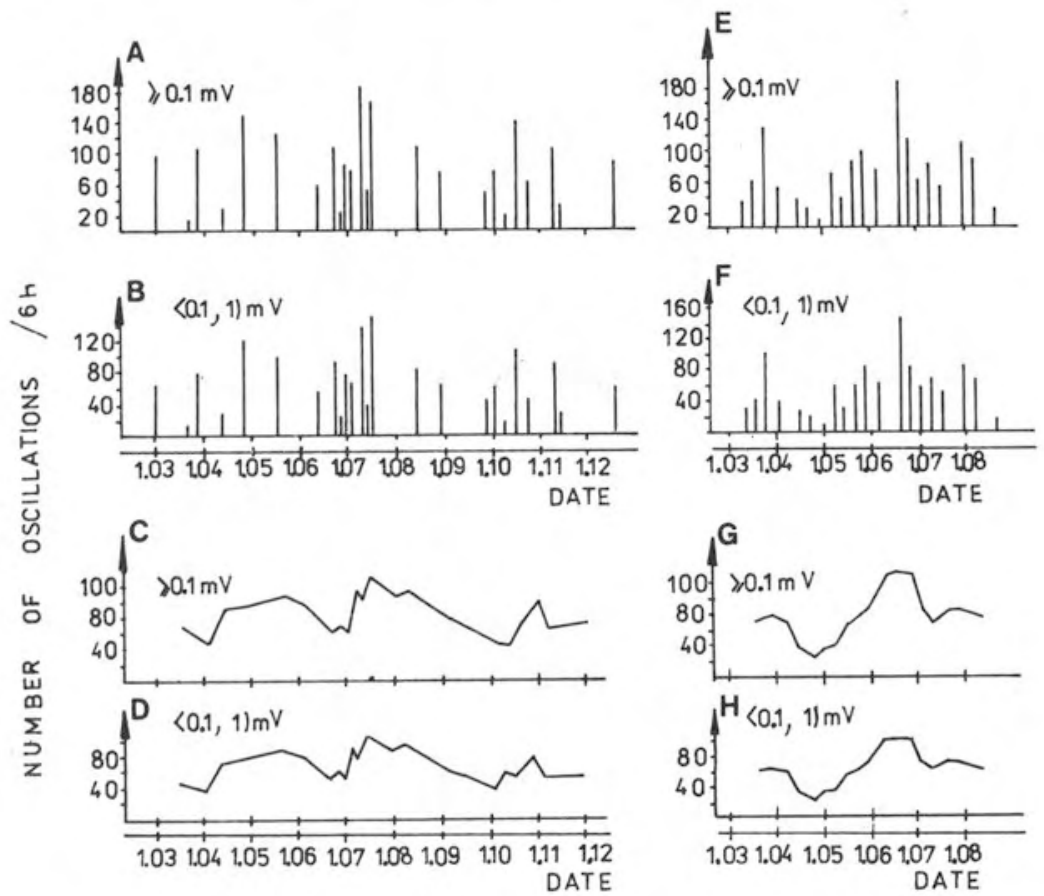

Fig. 1. Seasonal pattern of frequency of PD oscillations in the cambial region of the pine stem in 1984 (A, B, C, D) and in 1986 (E, F, G, H). A, B, E, F - each bar is a mean of two parallel measurements on separate tissue blocks taken from the same tree. C, D, G, H - seasonal trends flattened by means of a moving average for three terms. The diagrams are drawn for all measured PD oscillations: $\geqslant 0.1$ $\mathrm{mV}(\mathrm{A}, \mathrm{C}, \mathrm{E}, \mathrm{G})$ and for oscillations from the class of least amplitudes: $<0.1,1) \mathrm{mV}(\mathrm{B}, \mathrm{D}, \mathrm{F}, \mathrm{H})$ 
It turned out that the plots for the class of least oscillations: $<0.1,1) \mathrm{mV}$ and for the class including all recorded PD changes were particularly similar (e.g. Fig. $1 \mathrm{~A}$ and $\mathrm{B}$ ). This resulted from the very high contribution of low amplitude oscillations to the total number of PD changes.

\section{SOME PHYTOHORMONAL EFFECTS ON PD OSCILLATIONS}

In experiments with IAA applied by means of soaking the blocks the number of oscillations was slightly reduced as compared with controls (Fig. 2A). In the case of application of IAA in an agar strip to the apical end of the block, an increment in the number of PD changes was observed (Fig. 2B) especially in classes of medium and large oscillations. Thus, the effect of exogenous IAA depended upon the manner of hormone application.

Experiments with an inhibitor of polar auxin transport - 2,3,5-triiodobenzoic acid (TIBA) showed that in both variants of application (by means of soaking or agar strip) the chemical generally diminished the number of PD changes (Fig. 2C and D).

Since the above experiments suggest the involvement of IAA polar transport in modulation of PD oscillations, manipulations on growing trees were undertaken to differentiate natural auxin levels and auxin transport conditions in two locations on a tree stem. In this experiment with ring-barked stems, material for electrophysiological measurements was taken 9-10 months after making girdles, when, according to Wodzicki and Wodzicki (1973), the endogenous auxin level above the girdle was substantially higher than that below the band of removed tissues. The tissue blocks coming from above the girdles generated more oscillations in comparison with those taken beneath the girdles (Fig. 2E).

SPATIAL AND TEMPORAL COORDINATION OF PD OSCILLATIONS

Parallel, 2-channel recordings on one tissue block were performed using measuring electrodes placed 5 or $10 \mathrm{~mm}$ apart along the stem axis. To analyse possible coordination of PD changes recorded by both electrodes the events (oscillations from a given class of amplitudes) which occurred synchronously or almost synchronously (tolerance $\pm 2 \mathrm{~min}$.) were counted. The result of such counting was called "number of coincidences". This value was calculated for the pair of plots set up synchronously and also for cases when the time axis of one electrophytogram (namely: the one for the apical electrode) was successively shifted (with a 2-min. pitch) in relation to the other one (the electrophytogram for the basal electrode) in the negative or positive direction. As a result, a plot of the "number of coincidences" in the domain of "shift in time" was obtained (see Fig. 3). Separate plots were obtained for different classes of PD oscillation amplitudes. The clearest results were displayed by oscillations from the class: $<0.1,0.5) \mathrm{mV}$. The diagrams of the number of coincidences exhibit an 

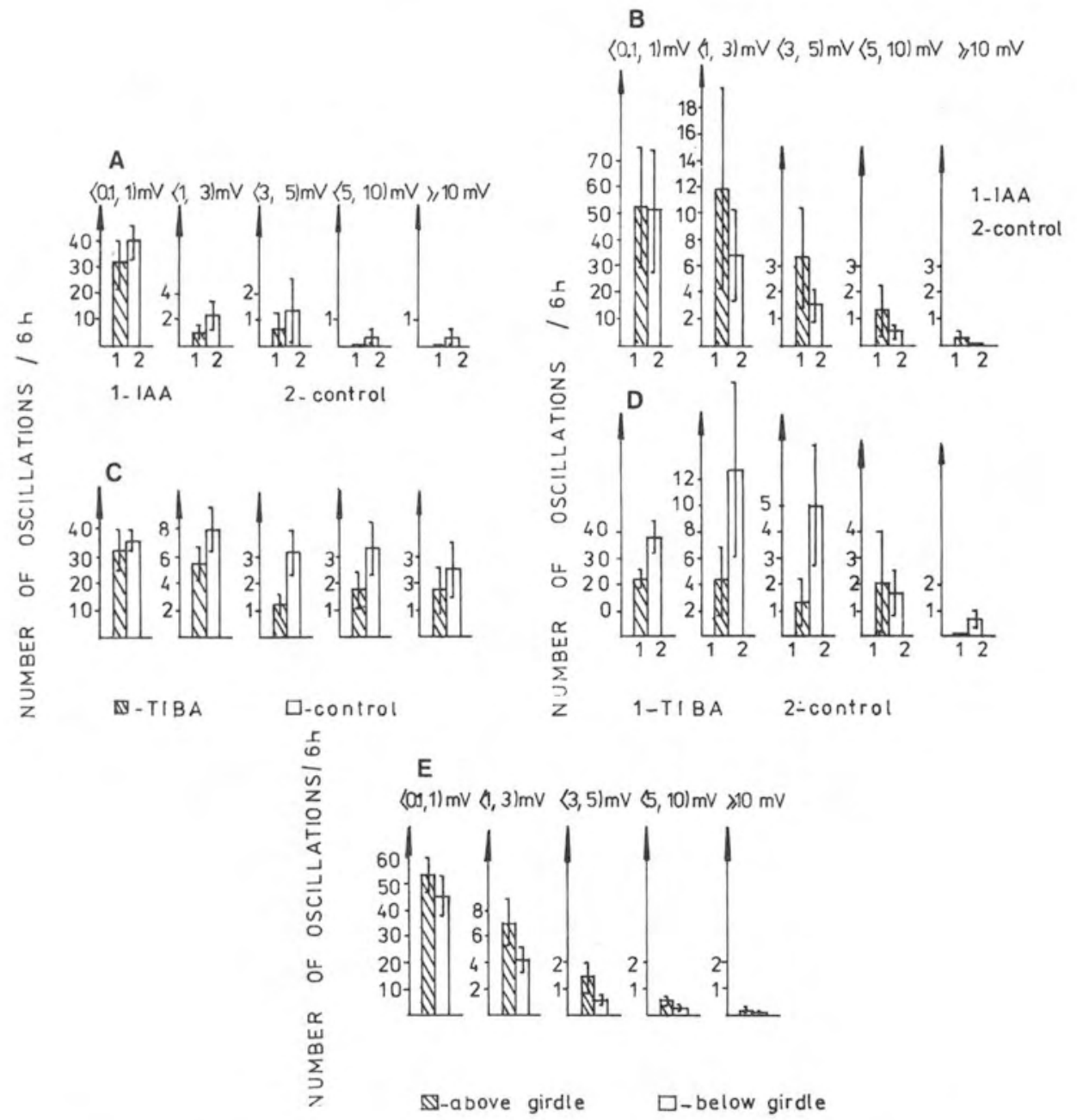

Fig. 2. Effects of growth regulators on PD oscillations. A and B - IAA exogenously applied to the block of tissue: A - tissue supplied with $5.7 \times 10^{-2} \mathrm{mM}$ IAA by means of soaking. Means of 5 measurements performed in April and May. B - tissue supplied with $5.7 \times 10^{-2} \mathrm{mM}$ IAA in an agar strip applied to the apical end of the tissue block. Means of 4 measurements performed in May. C and D - TIBA exogenously applied to the block of tissue: C - tissue supplied with $0.4 \mathrm{mM}$ TIBA by means of soaking. Means of 10 mesurements performed in the period: May-August. D - tissue supplied with $0.1 \mathrm{mM}$ TIBA in an agar strip applied to the apical end of the tissue block. Means of 3 measurements performed in April and May. E - experiments with ring-barked trees. Means of 17 replicates obtained in July and August. The diagrams are drawn for 5 different classes of amplitudes, from the least ones: $<0.1,1) \mathrm{mV}$ to the biggest ones: $\geqslant 10 \mathrm{mV}$ 
oscillation-like pattern with more or less distinct maxima and minima of different amplitudes (Fig. 3). The "period" of such a "secondary oscillation" is not stable and varies from several minutes to about $20 \mathrm{~min}$. This quasi-cyclic character of the plots suggests that PD changes are recorded by both measuring electrodes at similar frequency or that the frequency of oscillations at one electrode is a low multiple of the frequency at the second one. The theoretically possible maximum number of coincidences for a given pair of sequences was counted in the plots for all the recorded PD changes (for example: for two plots including 24 and 32 oscillations respectively, the maximum number of coincidences equals 24). Comparison of this value with the actual amplitude of the secondary oscillation enables us to estimate that ca. $10-25 \%$ of the total number of registered PD oscillations are responsible for secondary oscillations. This may suggest that probably this only portion behaves as propagating PD changes. The remaining $75-90 \%$ of PD changes result from random distribution of PD oscillations.
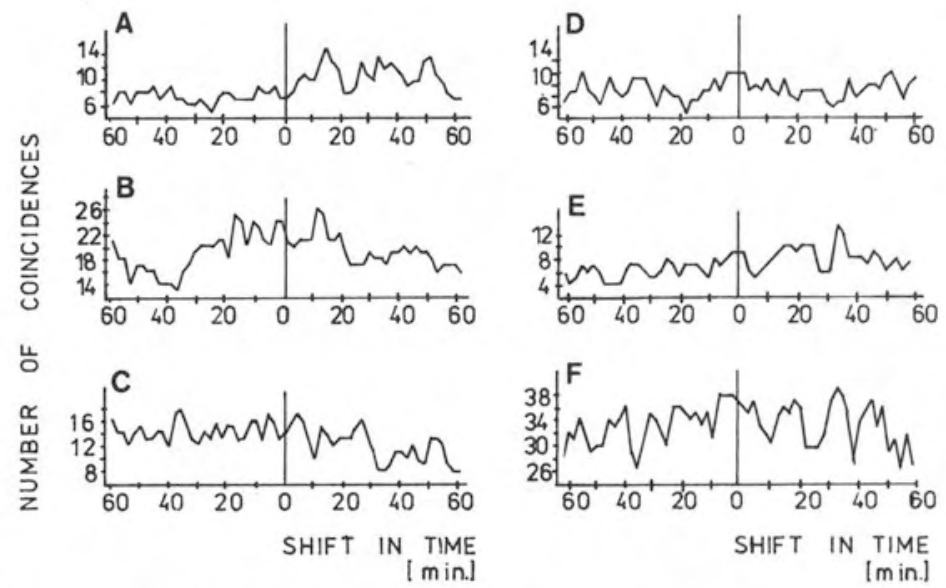

Fig. 3. Plots of the number of coincidences for PD oscillations from the class $<0.1,0.5) \mathrm{mV}$. Distance between measuring electrodes $5 \mathrm{~mm}(\mathrm{~A}, \mathrm{~B}, \mathrm{C})$ or $10 \mathrm{~mm}$ (D, E, F). The measurements were carried out on: April 22 (A), May 27 (B, C), May 3 (D), May 6 (E), May 12 (F)

Certain features of the secondary oscillations indicate that same portion of PD changes, especially those of least amplitudes $<0.1,0.5) \mathrm{mV}$ may be coordinated in space and time. Namely for measuring electrodes set up $5 \mathrm{~mm}$ apart in most cases the plot exhibits a minimum close to zero point of shift in time (see vertical lines in Fig. 3A, B, C). For electrodes $10 \mathrm{~mm}$ apart most plots have a maximum close to zero point (Fig. 3D, E, F). These minima for the distance between electrodes equal to $5 \mathrm{~mm}$ and maxima for the distance equal to $10 \mathrm{~mm}$ may suggest the existence in the tree stem of secondary oscillations with a wave-length of about $10 \mathrm{~mm}$. 


\section{DISCUSSION}

The minima observed in the seasonal pattern of frequency of PD oscillations (amplitude classes: $<0.1,1) \mathrm{mV}$ and $\geqslant 0.1 \mathrm{mV}$ ) may be correlated with some stages of xylem differentiation in adult pine trees grown in the same area. The first minimum (at the end of June) coincides roughly with the period of summer depression of cambial activity and with initiation of thick-walled tracheids of late-wood; the second (at the end of September) - with termination of cambial activity; the third one (in spring) — with the period just before the first cambial divisions in the season (W odzicki 1971, Wodzicki and Zajączkowski 1983, B o g a ci ńs ki et al. 1988). The results of seasonal measurements reported here are consistent with those obtained by Fen som (1963) who observed maximum intensity of PD oscillations in the tree trunks in spring, correlated with a high level of cambial activity.

In experiments with exogenously applied IAA a slight increment in the number of PD oscillations was observed only when the hormone was supplied to the apical end of the tissue. The number of oscillations was also greater in those blocks of tissue (taken from above the girdle) which had retained polar auxin transport due to preserved continuity with the upper parts of the tree stem containing the main auxin sources. Damping of the PD oscillations by TIBA confirms the importance of polar auxin transport in the cambial region for the electrophysiological activity recorded in this zone.

The relatively weak direct effects of IAA on the number of PD oscillations may result from the fact that $75-90 \%$ of recorded PD changes did not form a supracellular wave and were unable to propagate. This portion of oscillations probably might be unsusceptible to IAA, creating a high level of "noise" obscuring the results of phytohormone action. On the other hand, the quite weak effects of IAA in this study are in contrast with the results obtained with fusicoccin (FC) reported in the previous paper (K u r ek 1992). This coincides with investigations on the cellular level which report that $\mathrm{FC}$ hyperpolarizes $E_{m}$ to much greater extent than IAA does (M a r r è et al. 1974).

The effects of TIBA presented here and the results of seasonal measurements also suggest that low frequency transient PD changes may be a part of the mechanism underlying TIBA-induced formation of late-wood reported by Larson (1964) and Hejnowicz and Tom aszewski (1969).

The results of recordings from two electrodes located in one tissue block indicate that ca. $10-25 \%$ of PD oscillations, mainly the smallest ones, might create a supracellular wave with a period of about $10 \mathrm{~min}$. and "wave-length" - ca. $10 \mathrm{~mm}$ and, consequently, a velocity of propagation - ca. $60 \mathrm{~mm} / \mathrm{h}$. These preliminary estimations are different from those reported by $\mathrm{N}$ e w m a n (1963) for PD oscillations induced in the decapitated Avena coleoptile by IAA application: a period of ca. $20 \mathrm{~mm}$ and velocity of propagation - ca. $14 \mathrm{~mm} / \mathrm{h}$. On the other hand, the estimations presented here are close to the suggested 
parameteres of a supracellular wave resulting in polar transport of auxin in the cambial region of the stem of different woody species $(\mathrm{Z} \mathrm{a} \mathrm{ją} \mathrm{c} \mathrm{z} \mathrm{k} \mathrm{ow} \mathrm{ski} \mathrm{and}$ Wodzicki 1978, Zają czkowski et al. 1983, 1984). The supracellular auxin wave is considered by the above authors as a carrier of morphogenetic information. An analogous role might be attributed to the "secondary oscillations" described in this study which translocate 4-6 times faster than IAA molecules in polar transport $(10-15 \mathrm{~mm} / \mathrm{h}, \mathrm{Goldsm}$ it h 1969,1977$)$, this suggesting that the electrophysiological events in the cambial region could be involved in the mechanism of xylogenetic control and integration of morphogenetic processes in distant parts of a tree.

\section{Acknowledgment}

The author wishes to express his gratitude to Professor Stefan $\mathrm{Zaj}$ ą c zk ow ski for his valuable advice and discussions during this work and for critical reading of the manuscript.

\section{REFERENCES}

B a 11 a rin-D en ti A., C o cu c ci M., 1979. Effects of abscisic acid, giberellic acid and fusicoccin on transmembrane potential during the early phases of germination in radish (Raphanus sativus L.) seeds. Planta 146: 19-23.

B o g a ci ń sk i B., Z a ją c zk ow sk i S., W od z i c k i T.J., 1988. Zmienność inicjacji i kończenia sezonowej aktywności kambium w populacjach drzewostanowych Pinus sylvestris L. Sylwan 132: $17-26$.

Clel and R.E., Prins H.B.A., Harper J.R., Higinbotham N., 1977. Rapid hormone-induced hyperpolarization of the oat coleoptile transmembrane potential. Plant Physiol. 59: 395-397.

E th e r t on B., 1970. Effect of indole-3-acetic acid on membrane potential of oat coleoptile cells. Plant Physiol. 45: 527-528.

F en s o m D.S., 1963. The bioelectric potentials of plants and their functional significance. V. Some daily and seasonal changes in the electrical potential and resistance of living trees. Can. J. Bot. 41: 831-851.

Gold s m it h M.H.M., 1969. Transport of plant growth regulators. In: Physiology of plant growth and development. Ed. M.B. Wilkins. Mc Graw-Hill, London, pp. 127-162.

Gold s m it h M.H.M., 1977. The polar transport of auxin. Ann. Rev. Plant. Physiol. 28: 439-478.

Grad mann D., M u m mert H., 1980. Plant action potentials. In: Plant membrane transport: current conceptual issues. Eds. R.M. Spanswick, W.J. Lucas, J. Dainty. Elsevier, Amsterdam, pp. 333-344.

Hejnowicz A., T om a szewski M., 1969. Growth regulators and wood formation in Pinus silvestris. Physiol. Plant. 22: 984-992.

Hejnowicz Z., Pijanowski A., Głębicki K., 1986. An oscillatory component of propagated fluctuation electric potential in lupine shoot. Acta Soc. Bot. Pol. 55: 53-66.

I ch in o K., Kat ou K., Ok a moto H., 1973. Distribution of electric potential and ion transport in the hypocotyl of Vigna sesquipedalis. II. Axial potential difference. Plant Cell Physiol. 14: 127-137.

J a ffe L.F., 1982. Developmental currents, voltages and gradients. In: Developmental order: its origiz and regulation. Ed. S. Subtelny, P.B. Green. Alan R. Liss, New York, pp. 183-215. 
J a mes R.B., Pi erce W.S., Higin b ot h a $\mathrm{m}$ N., 1976. The effect of indolyl-acetic acid on cell electropotential and potassium flux in etiolated oat celeoptile tissue. In:Transmembrane ionic exchange in plants. Ed. M. Thellier, A. Monier, M. Demarty, J. Dainty. CNRS, Paris pp. 521-527.

K a t ou K., Ok a m o to H., 1970. Distribution of electric potential and ion transport in the hypocotyl of Vigna sesquipedalis. I. Distribution of overall ion concentration and the role of hydrogen ion in generation of potential difference. Plant Cell Physiol. 11: 385-402.

K u r e k W., 1992. Endogenous oscillation of electric potential difference in the cambial region of the pine stem. I. General characteristics of the oscillations. Acta Soc. Bot. Pol. 61: 221-220.

L a r s on P.R., 1964. Some indirect effects of environment on wood formation. In: The formation of wood in forest trees. Ed. M.H. Zimmermann. Academic Press, New York, pp. 345-365.

Marrè E., Lado P., Ferroni A., B allarin-Denti A., 1974. Transmembrane potential increase induced by auxin, benzyladenine and fusicoccin. Correlation with proton extrusion and cell enlargement. Plant Sci. Lett. 2: 257-265.

Medvedev S.S., M a rk ova I.V., 1990. How can the electric polarity of axial organs regulate plant growth and IAA transport? Physiol. Plant. 78: 38-42.

Morath M., Herte1 R., 1978. Lateral electrical potential following asymmetric auxin application to maize coleoptiles. Planta 140: 31-35.

New m a n I.A., 1963. Electric potentials and auxin translocation in Avena. Aust. J. Biol. Sci. 16: $629-646$.

Novak B., B entrup F., 1972. An electrophysiological study of regeneration in Acetabularia mediterranea. Planta 108: 227-244.

Sc ot t B.I.H., 1957. Electric oscillations generated by plant roots and a possible feedback mechanism responsible for them. Aust. J. Biol. Sci. 10: 164-179.

Sin ju k hi n A.M., G or ch a k ov V.V., 1966. Kharakteristika potencialov dejstvija provodjaschej sistemy steblja tykvy pri rozdejstvii razlichnykh razdrazhitelej. Fiziol. Rast. 13: 824-832.

Sinjuk hin A.M., Stolarek J., 1961. Izmenenie ritmicheskikh kolebanij biopotencialov v ontogeneze koleoptila kukuruzhy. Dokl. Ak. Nauk SSSR. 137: 725-727.

W e i s e n se 1 M.H., D or n A., J a f f e L.F., 1979. Natural $\mathrm{H}^{+}$currents traverse growing roots and root hairs of barley (Hordeum vulgare L.). Plant Physiol. 64: 512-518.

Wodzicki T.J., 1971. Mechanism of xylem differentiation in Pinus silvestris J. Exp. Bot. 22: 670-687.

Wod zi ck i T.J., W od zi ck i A.B., 1973. Auxin stimulation of cambial activity in Pinus silvestris L. II. Dependence upon basipetal transport. Physiol. Plant. 29: 288-292.

W od zicki T.J., Zaj a c z k ow sk i S., 1983. Variations of seasonal cambial activity and xylem differentiation in a selected population of Pinus silvestris. Folia Forest. Pol. Ser. A 25: 5-23.

Yule G.U., Kenda11 M.G., 1966. Wstęp do teorii statystyki. PWN, Warszawa, 684 pp. (translated from English).

Zajączkowski S., Wodzicki T.J., 1978. Auxin and plant morphogenesis - A model of regulation. Acta Soc. Bot. Pol. 47: 233-243.

Zajączkowski S., Wodzicki T.J., Bruinsma J., 1983. A possible mechanism for whole-plant morphogenesis. Physiol. Plant. 57: 306-310.

Zajączkowski S., Wodzicki T.J., R omberger J.A., 1984. Auxin waves and plant morphogenesis. In: Encyclopedia of plant physiology, New Series, vol. 10. Hormonal regulation of plant development II. Ed. T.K. Scott. Springer, Berlin, pp. 244-262. 
Endogenne oscylacje różnicy potencjalów elektrycznych $w$ regionie kambialnym pnia sosny. II. Potencjalny zwiazek oscylacji z procesami ksylogenezy

\section{Strzeszczenie}

Badano bezpośrednie i pośrednie związki między procesami ksylogenetycznymi i endogennymi oscylacjami różnicy potencjałów elektrycznych (PD) generowanymi w regionie kambialnym izolowanych wycinków pnia sosny zwyczajnej. Częstość tych wahań PD zmieniała się w trakcie sezonu wegetacyjnego i wykazywała trzy minima, które odpowiadały w przybliżeniu okresom inicjacji i kończenia aktywności kambialnej i rozpoczęcia różnicowania słoja na drewno późne. Oscylacje były thumione przez TIBA - inhibitor polarnego transportu auksyny, a stymulowane przez IAA, ale tylko w przypadku, gdy fitohormon ten dostarczano do apikalnego końca wycinka pnia. Sugeruje to istnienie związku między rejestrowanymi oscylacjami PD i polarnościowymi aspektami transportu auksyny. Wyniki 2-kanałowych pomiarów w jednym wycinku pnia sugerują ponadto, że część rejestrowanych oscylacji (10-25\%) przejawia koordynację przestrzenno-czasową: ta frakcja wahań PD tworzy wzdłuż osi pędu wzór falowy. Ta „fala” mogłaby być fizycznym nośnikiem informacji koordynującej procesy wzrostu i różnicowania na znacznych obszarach pnia rośliny drzewiastej. 